\title{
Impact of Capital Adequacy on Bank Stability in Lebanon
}

\author{
Dr. Racha Ghayad \\ Assistant Professor, Head of Finance Department, Faculty of Economic Sciences and \\ Business Administration, Lebanese University, Lebanon
}

\section{Diana Noura}

Master's degree in Finance and Banking, Lebanese University, Lebanon

\begin{abstract}
:
This research paper intention is to study the capital adequacy requirements in the Lebanese banks and the effect of this ratio on the financial stability. Capital adequacy ratio and Altmans zscore (representing stability of banks) were collected from a sample of 8 Lebanese banks in the time between 2009 to 2018. The collected data is analyzed using SPSS software to reach conclusions that serves the topic of study. 8 simple linear regressions are conducted, among a confidence level of $95 \%$ and a level of error 5\%. Each simple regression has a dependent variable (Altman's Z-score) which represents the stability of the bank, and an independent variable (Capital adequacy ratio). The results show that almost in all banks (except bank MED) there was no significant impact of CAR on the stability of the banks. This result shows that the commitment of Lebanese commercial banks under the monitoring of the central bank was not enough to keep the financial system stable, which is a logical conclusion after what happened in 2019 where the financial system has collapsed and the commercial banks faced a severe crisis in its liquidity and reputation. Although the central bank in Lebanon was in a full compliance with Basel requirements concerning minimum capital over years, the Lebanese banking sector has collapsed and bankrupted. Also, depositors were not protected and they lost their deposited money in the bank. In other words, capital requirements in Lebanon did not prevent banks from engaging in excessive risk-taking and enhance financial stability.
\end{abstract}


Thus, the problem of the Lebanese banking sector could be mismanagement, concentration of the loans portfolio in Eurobonds and with the central bank, and many other factors that caused the financial collapse in Lebanon.

Keywords: Impact, Capital adequacy, Bank stability, Lebanon

تهذف هذه الورقة البحثية إلى دراسة منطلبات كفاية رأس المال في البنوك اللبنانية وأثر هذه النسبة على الاستقرار المالي. تم جمع نسبة كفاية رأس المال واستقر ار البنوك من عينة من ثمانية بنوك لبنانية في الفترة ما بين 2009 إلى 2018. ويتم تحليل البيانات التي تم جمعها باستخدام برنامج SPSS للوصول إلى استتناجات تخدم موضوع الدر اسة. تم إجر اء ثمانية انحدارات خطية بسيطة، بين مستوى ثقة 95\% ومستوى خطأ 5\%. كل انحدار بسيط له متغير تابع (درجة ألتمان Z) التي تمثل استقرار البنك، ومتغير مستقل (نسبة كفاية رأس المال). تظهر النتائج أنه في جميع البنوك تقريبًا (باستثناء بنك MED) لم يكن هناك تأثير كبير لـ CAR على استقر ار البنوك. تظهر هذه النتيجة أن النزام البنوك التجارية اللبنانية تحت رقابة البنك المركزي لم

يكن كافياً للحفاظ على استقرار النظام المالي، و هي نتيجة منطقية بعد ما حدث في عام 2019 حيث انهار النظام المالي وواجهت البنوك التجارية أزمة شديدة. أزمة السيولة والسمعة. على الرغم من أن البنك المركزي في لبنان لبنان كان في حالة امتثال كامل لمنطلبات بازل المتعلقة بالحد الأدنى لر أس المال على مر السنين، إلا أن القطاع المصرفي اللبناني انهار ومفلس. كما أن

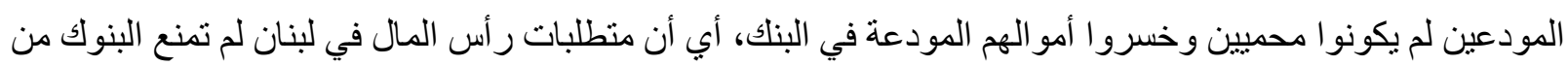
الانخر اط في المجازفة المفرطة وتعزيز الاستقرار المالي. وبالتالي، يمكن أن تكون مشكلة القطاع المصرفي اللبناني هي سوء الإدارة، وتركّز محفظة القروض في سندات اليوروبوند ومع البنك المركزي، و العديد من العوامل الأخرى التي تسبيت في الانهيار المالي في لبنان. الكلمات المفتاحية: الأثر، كفاية رأس المال، استقرار المصارف، لبنان 


\section{Introduction}

The recent global financial crisis, which lasted from 2007 to 2009, underscored the importance of bank performance in both national and international economies. The performance of banks must be closely monitored and supervised at all times. Because banks have such a large impact on the economy, the banking sector has received a lot of attention in terms of regulation and supervision (Barth, Caprio, G.J., \& Levine, 2006). The banking system's poor performance has been ascribed to a number of issues, including insufficient capital, large non-performing assets, and so on, all of which have led to repeated distress in the banking sector and the failure of some institutions (Obadan, 2004). The global financial crisis has had a significant impact on the global banking industry's financial status and performance. As an outcome, several banks went insolvent, unable to meet capital requirements and unable to sustain potential asset losses in the future. Bankruptcies have become more common in recent years, and dealing with them has gotten more expensive. Over the last few years, bank regulators have implemented a number of initiatives to tie commercial bank regulation and supervision to risk and financial sustainability. Bank supervision has been bolstered by regulators maintaining an acceptable and sufficient level of capital sufficiency.

The Basel Committee on Banking Supervision, which was founded by the central bank governors of the Group of Ten countries in 1975, developed the worldwide recognized and approved capital rules. The group worked out the specifics of the agreed-upon framework for determining capital sufficiency and the minimal criteria. The Basel Capital Accord of 1988 established the definition of capital and differentiated between core (Tier 1) and supplementary (Tier 2) capital. The Basel Committee introduced capital adequacy regulation in 1988, requiring globally active banks to maintain a minimum capital of $8 \%$ of risk adjusted assets, with Tier I capital (equity capital and disclosed reserves) and Tier II capital (long term debt, undisclosed reserves, and hybrid instruments), which has been adopted by over 100 countries (Aspal, 2014). To minimize risks and bankruptcy, financial institutions and banks must maintain capital adequacy at a particular minimum level. Capital requirements authorities aim to ensure that risk exposure on financial institutions and banks is supported by an adequate level of capital that can withstand potential losses. This assures that banks promote their reserve of assets that can be used to settle liquidation claims. 


\subsection{Research Problem}

The efforts of the international financial and banking institutions, especially what was done by the Basel Committee to establish international decisions on banking capital adequacy standards, and the risks associated with banking, in light of the increasing trend towards financial globalization in recent years, which led to the increase and spread of financial crises. As a result of this trend, some countries were affected by the crises of other countries due to the infection. Recent studies that dealt with the causes of the outbreak of financial crises in six developing countries and their countries pointed to the important role played by weaknesses in national financial legislation in terms of igniting or exacerbating crises. Although these decisions have been accepted, there are a number of related issues that need further research, such as the impact of the bank adequacy ratio on the financial stability of commercial banks.

\subsection{Research question and hypothesis}

Based on the previous studies, research question is "To what extent does the capital adequacy ratio affect the financial stability of the Lebanese banks?',

Based on literature review and related studies, the research hypothesis is:

\section{There is a significant relationship between bank's adequacy ratio and the financial stability} of the bank

\section{Literature Review}

In this section, we discuss several capital adequacy theories that are pertinent to this research. The buffer, portfolio, expenditure, and charter value theories are examples of these ideas.

\subsection{Capital adequacy in literature}

Calem and Rob (1996)proposed the buffer theory, which posits that a bank whose capital drops towards the minimal regulatory capital ratio may have an incentive to beef up its capital and reduce risk in order to avoid regulatory costs of breaching capital requirements. According to the hypothesis, banks try to keep a buffer of surplus capital to avoid falling below the minimum capital requirement, especially if the capital adequacy ratio is excessively volatile.

The portfolio regulation hypothesis asserts that banks must be appropriately regulated to ensure the financial system's safety, stability, and soundness, 
as well as their capacity to meet their liabilities on time. As a result, regulatory authorities asserts that capital restrictions will force banks to retain fewer risky assets (Merton, 1977). This theory idea serves as a measure for assessing the banking system's stability.

Other theory, Williamson's expense theory, as cited in (Igbinosa \& Naimo, 2020), is also known as the theory of management discretion. It claims that instead of maximizing shareholder wealth, managers are more likely to pursue policies that serve their personal interests or enhance their own utility. This might lead to excessive risk-taking and overtrading, which would deplete the bank's capital basis.

Finally, Marcus in 1984 as mentioned in (Igbinosa \& Naimo, 2020) introduced the charter value hypothesis, which asserts that banks typically keep more capital in addition to the required capital to defend themselves from financial crises and manage default risk.

After introducing capital adequacy in this chapter; which is the independent variable in this study that influence banks' stability, this section introduces the impact of capital adequacy ratio on the stability of banks.

\subsection{Impact of CAR on banks' Stability}

Capital is the amount of the bank's long-term funds that are available for financing the bank's assets and also serve as a buffer against losses (Athanasoglou, Sophocles \&Matthaios, 2005).

Capital adequacy is the appropriate amount of capital a bank or other financial intermediary must have for the conduct of its business as stipulated by its regulatory authority to enable it withstand the risks it is exposed to and absorb losses without putting depositors at risk (Ongore\& Kusa, 2013).

Capital adequacy is the first component of the CAMELS framework and one of the most important indications of the financial well-being or soundness of a bank and it helps to safeguard the ability of the bank to absorb losses and overcome distress that may arise by its taking on certain business risks or that may be due to considerable macroeconomic imbalances. Thus, higher bank capital limits the probability of bank distress (Diamond \&Rajan, 2000) and reduces bank exposure to systemic risk 
Capital adequacy ratio is the proxy for capital adequacy, and it reflects the internal financial capacity of the bank (Dang, 2011). Capital adequacy ratio is empirically used to measure capital adequacy and it is computed as the ratio of total capital to total assets (total risk weighted assets), or through other ratios such as the ratio of total equity to total assets, the ratio of equity to net loans or the ratio of equity to debts (Roman \&Sargu, 2013).

According to Sangmi and Nazir (2010), capital adequacy ratio has a positive relationship with bank stability and profitability. Contrariwise, Igbinosa, Ogbeide and Akanji (2017), posit that capital adequacy has a negative effect on the performance of Nigerian banking sector.

\subsection{Previous Studies:}

- (ABDU1, 2017) study examines the impact of many variables on banks' performance in Nigeria. Data was acquired from nine deposit money institutions with major international operations using the cross-panel methodology. The findings show that capital adequacy has a beneficial impact on a bank's profitability. This is consistent with theoretical expectations as well as other authors' findings. To maintain banks' financial strength and stability in Nigeria, the study recommends that bank regulators focus not only on capital adequacy but also on supervisory review and market discipline.

- (Sang, 2021)aims in his research is to give further empirical evidence on the impact of the capital adequacy ratio, as well as control and micro factors, on commercial bank financial stability in emerging countries like Vietnam. The capital adequacy ratio has a favorable link with the financial stability of Vietnamese commercial banks over the study period, according to empirical research findings; the study proposes some policy implications to improve the financial stability of Vietnamese commercial banks. The publication also identified four study constraints in terms of data, research samples, techniques, and research models, allowing for more comprehensive research in the future.

- (Igbinosa \& Naimo, 2020) study looks at capital adequacy and bank stability/soundness in Sub-Saharan Africa. As a result, capital adequacy is a major condition that regulated banks in any part of the world, including Sub-Saharan Africa, must meet in order to promote bank stability and soundness. 
Over the period 2007-2016, the study examines the relationship between capital adequacy and bank stability/ soundness in Sub-Saharan Africa. The study analyzes secondary data from the World Bank Global Financial Development Indicators, 2018, using the panel least squares (PLS) regression technique. The Z-score serves as a proxy for the dependent variable, bank stability/soundness, the capital adequacy ratio serves as a proxy for the independent variable, capital adequacy. In Sub-Saharan Africa, and capital adequacy has a negative and considerable impact on the banks' stability and soundness.

- (SENTERO, 2012) adopts a quantitative research design was used in this study. The study's target population was all 43 commercial banks operating in Kenya that had been regulated and registered under the Banking Act Cap. 488 in the previous five years. The value of the $\mathrm{F}$ statistic indicated that the overall regression model is significant hence it has some explanatory value. There is a significant impact of the predictor variables of capital adequacy ratio and the efficiency of commercial banks in Kenya.

- (Eichberger \& Summer, 2015) Study investigates the influence of capital adequacy regulations on bank insolvency and overall investment. We provide a banking system model that includes the interaction of numerous diverse banks with the real sector, interbank credit relationships resulting from bank liquidity management, and an insolvency mechanism. This allows us to investigate how capital adequacy regulations affect systemic risk. We can examine the influence of legislation on contagious defaults resulting from mutual credit relationships in particular. We show that the influence of capital adequacy on systemic stability is equivocal, and that placing capital limitations on banks may potentially raise systemic risk.

- (OGBOI \& UNUAFE, 2013) Look in their study at impact of credit risk management and capital sufficiency on banks' financial performance in Nigeria using a time series and cross-sectional data from selected banks' annual reports and accounts from 2004 to 2009.

The findings revealed that the solid credit risk management and capital adequacy had a beneficial impact on bank financial performance, with the exception of loans and advances, which had a negative impact on banks' profitability over the study period.

- (Vyas, 2008) Aims in his study to examine the impact of bank level characteristics such as capital to risk weighted assets ratio, non-interest income, 
and net interest margin on bank performance as assessed by return on assets of scheduled commercial banks in India. The methodology used is panel data analysis conducted over the period 1997-2007. All of these elements have a favorable and considerable impact on profit. The findings also show that the profitability of public sector banks, Indian private banks, and foreign banks operating in India is not significantly different.

- (Datta \& Mahmud, 2018) Article investigates the impact of many bank-specific characteristics, such as capital sufficiency, on the profitability of Bangladesh's publicly traded commercial banks. According to the findings of this study, banks' regulatory capital exceeds the Basel II minimum capital requirement. Explanatory variables such as capital adequacy, operational efficiency, and loan structure have all been shown to be positively connected to a bank's profitability.

Many studies have related between CAR and the performance and situation of banks.

Some has tested the impact of CAR on stability, some on profitability and efficiency, and many other characteristics of banks.

This study focuses on the impact of CAR on stability of banks, where it represents the stability by Altman's Z-score. The use of Altman's z-score is due that many studies have used it to represent the stability of banks, and because the data of this variable is available. For instance, Altman's Z-score is used as an indicator of financial health of banks in many studies concerning Lebanon;

- (Ghosn, 2019) also tested the financial health of four listed Lebanese banks (Byblos, BLOM, BOB, and BLC). His study covered the period 2013 - 2017. He applied the Zscore for emerging markets and non-manufacturing companies. Ghosn found out that the adoption of the Z-score (equation for non-manufacturing organization) is inappropriate to be implemented on banks within the Lebanese market. The Altman Z-score is a metric that assesses a company's health and likelihood of going bankrupt. An Altman Z-score value is calculated using a number of critical ratios. Professor Edward Altman of New York University established the Z Score in 1960. The approach of the formula has been employed in a number of situations and places. Its legitimacy has been shown through forty years of public scrutiny. 


\section{Methodology}

This part outlines how the data and information for this study were gathered. First, the primary purpose of the study will be re-stated, as will the hypotheses that will be tested in order to determine the dependent and independent variables. The research framework, including the philosophy, approach, strategy, data collection methods, time period, and data collection tools and processes, will be illustrated in this chapter.

\subsection{Research Methodology}

Institutions use research to uncover and organize items in a systematic manner. It's a structure that's utilized to plan the study's actions and come up with solutions to the study problem. Quantitative research has been introduced to reach the outcomes. By carefully defining, clarifying, thoughtfully understanding, and analyzing the association between the capital adequacy of a sample of Lebanese banks and their stability (using Altman's z-score).

The research is a theoretical, analytical, and intellectual examination of data and information with the goal of gaining a better understanding of the subject. It comes with extra tools for collecting, defining, visualizing, criticizing, and evaluating data. It necessitates a theoretical knowledge of the method or combination of methods to be used, as in this study. Then by using information obtained from financial statements of the selected banks.

\subsection{Research Design}

The research context and arrangement make up the research architecture. The purpose of this research is to determine and investigate the impact of capital adequacy on Lebanese banks' stability. In this study, the quantitative technique was used to collect data from the selected banks annual financial statements, retrieved from their websites. In addition, the research technique was descriptive and inferential with quantitative research in order to gain a better understanding of the strength and the way capital adequacy influences banks' stability.

The descriptive, inferential, and predictive statistical analyses are used to collect and interpret the objective data for this quantitative investigation. The findings will examine into the hypotheses that have been proposed and will assess whether they are accepted or rejected. 


\subsection{Research Strategy}

The quantitative study was used as the research method to achieve the analysis's final purpose (approach). In addition to the data retrieved from banks, as well as expert feedback and comments, observation was used to obtain data for the quantitative analysis from references based on previous research and information from the economist and relevant websites. The study conducted extensive research to gather information about the variables of the study. This method is very good in gathering data from a vast area in order to research a subject.

\subsection{Variables of Study}

First variable of the study is the capital adequacy ratio (CAR) which is collected from the financial statements of the 8 banks of the study.

Second variable of the study is the bank stability, which is represented by Altman's Z-score.

Z-score for financial banks:

$\mathrm{Z}=6.56 \mathrm{~T} 1+3.26 \mathrm{~T} 2+6.72 \mathrm{~T} 3+1.05 \mathrm{~T} 4$

$Z=3.25+6.56 X_{1}+3.26 X_{2}+6.72 X_{3}+1.05 X_{4}$ (for emerging markets)

Where:

- $\mathbf{T 1}$ = (Working Capital / Total Assets)

- T2 $=($ Retained Earnings $/$ Total Assets $)$

- $\mathrm{T3}=($ EBIT / Total Assets $)$

- T4 = (Market Value of Equity / Total Liabilities)

\subsection{Data Collection}

Every study investigation needs both data and information to be successful. In this study, a secondary data was the source of the research information. Secondary sources are used in this research to acquire data. Data acquired from books, blogs, websites, records, journals, papers, and previous studies. 
The quantitative data collected for analysis are secondary data from websites of a sample of Lebanese banks; where financial statements are used to collect capital adequacy ratio and Altman's z-score of banks through many years.

\subsection{Data Analysis}

The collected data is analyzed using SPSS software to reach conclusions that serves the topic of study. Multiple simple linear regressions are conducted, among a confidence level of $95 \%$ and a level of error 5\%. Each simple regression has a dependent variable (Altman's Z-score) which represents the stability of the bank, and an independent variable (Capital adequacy ratio). The impact of capital adequacy is significant if the p-value is less than 0.05. In addition, the sign of the coefficient of regression will indicates if the impact is positive or negative.

Thus, hypothesis of study is validated or not using simple linear regression.

\section{Empirical Study}

After introducing the study variables in the previous chapters of this study, this chapter presents the empirical part of the study; explaining the Lebanese current situation and crisis, and conducting regressions to test the impact of the study dependent variable (Capital adequacy) on the dependent variable (banks' stability represented by Altman's z-score).

\subsection{Lebanese Economic Crisis and Lebanese Banks}

The banking sector in Lebanon has historically supported the Lebanese economy by funding the country's sovereign debt. However, a few missteps, characterized by non-diversification of the banks' investments and serving governmental debt (through investments in Treasury bills and Eurobonds) funded from their agents' deposits, have resulted in a severe financial crisis, putting Lebanese banks on the front lines of the crisis (Chbeir, 2019). The largest difficulty confronting the Lebanese economy for the past two decades has been debilitating indebtedness, as the government has been mired in a massive public burden of debt and repeated budget deficits as shown in the figure bellow. 


\section{Figure 1: A Historical Analysis of Lebanon's Public Debt}

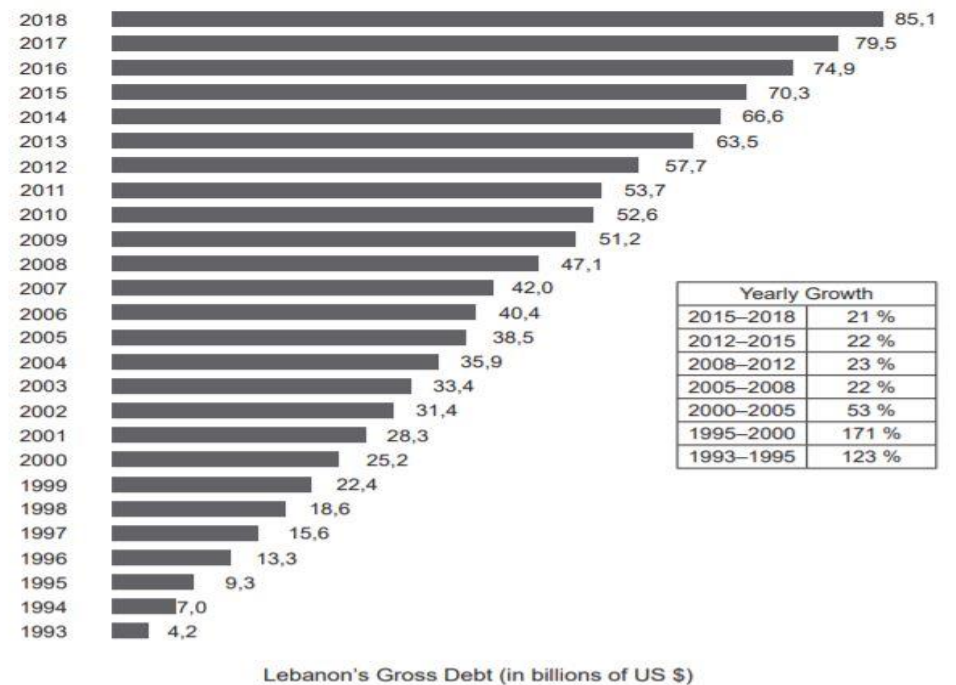

Since 2016, the Banque du Liban (BDL) has participated in sovereign bond swaps with banks in order to refinance state debt and rebuild foreign exchange reserves. According to reports, this approach assisted banks in generating capital profits. Banks, on the other hand, raised interest rates in order to attract new dollar deposits, which they then recycled at the BDL. In the end, such a "financial engineering" approach was shown to be unsustainable because it resulted in BDL losses and imprisoned dollar bank resources.

Following widespread protests against corruption and economic mismanagement on October 17th, which resulted in bank closures, restrictions on withdrawals and other unofficial capital control measures were enforced for the first time in November 2019. The country's complicated economic problem stems from a number of factors, including corruption, the Syrian civil war, the government's failure to execute critical reforms, and an aging electricity industry that drains billions from state coffers without producing much or generating enough revenue. And the situation has only worsened as public trust in the banking system erodes, businesses close or reduce production, and thousands of citizens lose their jobs. To be clear, the banking crisis stems from banks' lending money to the government through investing in Eurobonds and Treasury bills, and profiting in the process. 
However, the lending was financed by the banks' agents' deposits, and the institutions did not make a concerted attempt to diversify their holdings (Elia, 2020).

Banks were severely impacted when the government failed and went into financial trouble. People are ready to withdraw their foreign currency due to the crisis, in the hopes of protecting their savings from inflation, economic collapse, and potential haircuts, putting banks on the front lines of the fight against this "capital flight" (Elia, 2020).

\subsection{Descriptive Analysis}

The average capital adequacy ratio (main variable of the study) of Lebanese banks is plotted against time in years.

The figure below (figure 4) represents the average capital adequacy of the 8 banks selected in the sample of study.

In 2009, capital adequacy ratio was 12.655 and it increases slightly the next year, before it then started decreasing to reach its minimum in 2011 at a capital adequacy equal to 11.498.

After 2011, the Lebanese central bank started to increase the minimum requirement of the capital adequacy. This results in a continuing increase of the capital adequacy of the selected banks in the next years until it reaches the maximum at year 2018 with a value 18.943 of capital adequacy. 
Figure 2: Capital adequacy over years

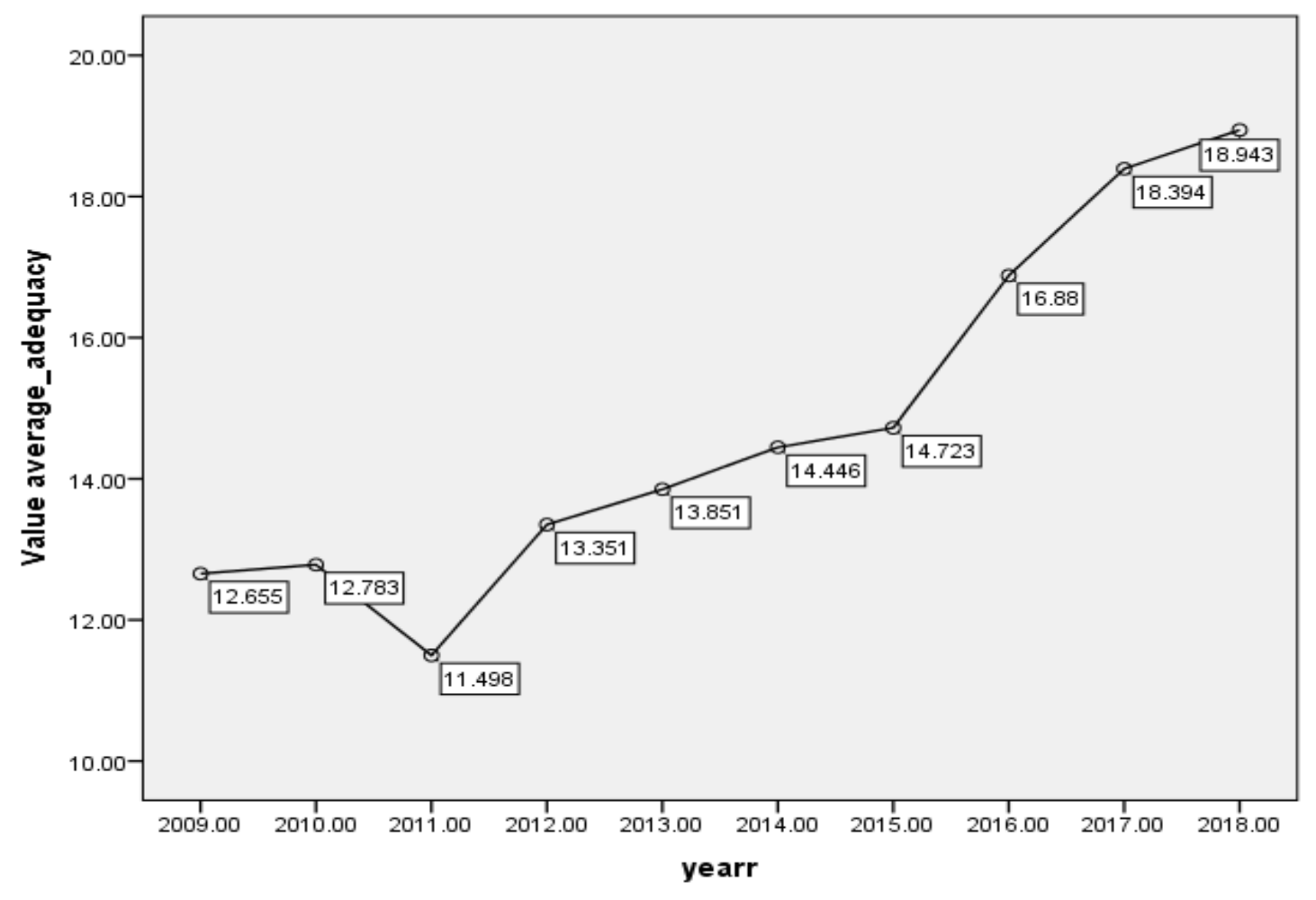

\subsection{Validating Hypothesis}

The main hypothesis: Capital Adequacy has significant impact on bank stability

\subsubsection{Bank Audi}

Ha: Capital Adequacy has significant impact on Audi Bank Stability

As shown in the below table, there is no significance impact of CAR on bank stability.

Table 1: Impact of capital adequacy on stability of AUDI Bank

\begin{tabular}{|c|c|c|c|c|c|}
\hline \multirow[b]{2}{*}{ Model } & \multicolumn{2}{|c|}{$\begin{array}{c}\text { Unstandardized } \\
\text { Coefficients }\end{array}$} & \multirow{2}{*}{$\begin{array}{c}\begin{array}{c}\text { Standardized } \\
\text { Coefficients }\end{array} \\
\text { Beta } \\
\end{array}$} & \multirow[b]{2}{*}{$\mathrm{t}$} & \multirow[b]{2}{*}{ Sig. } \\
\hline & $\mathrm{B}$ & Std. Error & & & \\
\hline $\begin{array}{ll}1 & \text { (Constant } \\
& \text { ) }\end{array}$ & .825 & 1.113 & & .742 & .479 \\
\hline AUDI & -.045 & .079 & -.198 & -.571 & .583 \\
\hline
\end{tabular}




\subsubsection{Bank Byblos}

\section{H b: Capital Adequacy has significant impact on Byblos Bank Stability}

As shown in the below table, there is no significance impact of CAR on bank stability.

Table 2: Impact of capital adequacy on stability of Byblos Bank

\begin{tabular}{|c|c|c|c|c|c|}
\hline \multirow[b]{2}{*}{ Model } & \multicolumn{2}{|c|}{$\begin{array}{l}\text { Unstandardized } \\
\text { Coefficients }\end{array}$} & \multirow{2}{*}{$\begin{array}{c}\begin{array}{c}\text { Standardized } \\
\text { Coefficients }\end{array} \\
\text { Beta }\end{array}$} & \multirow[b]{2}{*}{$\mathrm{t}$} & \multirow[b]{2}{*}{ Sig. } \\
\hline & B & Std. Error & & & \\
\hline $\begin{array}{l}1 \quad \text { (Constant } \\
\text { ) }\end{array}$ & 1.995 & .629 & & 3.174 & .013 \\
\hline BYBLOS & -.043 & .038 & -.366 & -1.113 & .298 \\
\hline
\end{tabular}

\subsubsection{Blom Bank}

\section{H c: Capital Adequacy has significant impact on Blom Bank Stability}

As shown in the table of Anova as well as coefficients, the independent variable "Blom Bank" is not significant at a 95\% confidence level. Thus, no significant impact of capital adequacy on Blom bank stability positively or negatively.

Table 3: Impact of capital adequacy on stability of Blom Bank

\begin{tabular}{|c|c|c|c|c|c|}
\hline \multirow[b]{2}{*}{ Model } & \multicolumn{2}{|c|}{$\begin{array}{l}\text { Unstandardized } \\
\text { Coefficients }\end{array}$} & \multirow{2}{*}{$\begin{array}{c}\begin{array}{c}\text { Standardized } \\
\text { Coefficients }\end{array} \\
\text { Beta }\end{array}$} & \multirow[b]{2}{*}{$\mathrm{t}$} & \multirow[b]{2}{*}{ Sig. } \\
\hline & B & Std. Error & & & \\
\hline $\begin{array}{ll}1 & \text { (Constant } \\
& \text { ) }\end{array}$ & 1.102 & .368 & & 2.995 & .017 \\
\hline BLOM & -.030 & .022 & -.431 & -1.350 & .214 \\
\hline
\end{tabular}




\subsubsection{SGBL Bank}

\section{H d: Capital Adequacy has significant impact on SGBL Bank Stability}

As shown in the table of Anova that there is overall insignificance among the independent variable as well as coefficients, the independent variable "SGBL Bank" is not significant at a 95\% confidence level. Thus,no significant impact of capital adequacy on SGBL bank stability positively or negatively.

Table 4: Impact of capital adequacy on stability of SGBL Bank

\begin{tabular}{|c|c|c|c|c|c|}
\hline \multirow[b]{2}{*}{ Model } & \multicolumn{2}{|c|}{$\begin{array}{l}\text { Unstandardized } \\
\text { Coefficients }\end{array}$} & \multirow{2}{*}{$\begin{array}{c}\begin{array}{c}\text { Standardized } \\
\text { Coefficients }\end{array} \\
\text { Beta }\end{array}$} & \multirow[b]{2}{*}{$\mathrm{t}$} & \multirow[b]{2}{*}{ Sig. } \\
\hline & B & Std. Error & & & \\
\hline $\begin{array}{l}1 \quad \text { (Constant } \\
\text { ) }\end{array}$ & .226 & .477 & & .474 & .648 \\
\hline SGBL & .006 & .036 & .059 & .167 & .871 \\
\hline
\end{tabular}

\subsubsection{BBAC Audi}

\section{He: Capital Adequacy has significant impact on BBAC Bank Stability}

As shown in the table of Anova that there is overall insignificance in addition to coefficients table, the independent variable "BBAC Bank" is not significant at a 95\% confidence level. Thus, no significant impact of capital adequacy on BBAC bank stability.

Table 5: Impact of capital adequacy on stability of BBAC Bank

\begin{tabular}{|c|c|c|c|c|c|}
\hline \multirow[b]{2}{*}{ Model } & \multicolumn{2}{|c|}{$\begin{array}{l}\text { Unstandardized } \\
\text { Coefficients }\end{array}$} & \multirow{2}{*}{\begin{tabular}{|c|}
$\begin{array}{c}\text { Standardized } \\
\text { Coefficients }\end{array}$ \\
Beta \\
\end{tabular}} & \multirow[b]{2}{*}{$\mathrm{t}$} & \multirow[b]{2}{*}{ Sig. } \\
\hline & B & Std. Error & & & \\
\hline $\begin{array}{ll}1 \text { Constant } \\
\end{array}$ & 1.326 & 2.100 & & .632 & .545 \\
\hline $\mathrm{BBAC}$ & -.085 & .158 & -.188 & -.541 & .603 \\
\hline
\end{tabular}




\subsubsection{Bank MED}

\section{H f: Capital Adequacy has significant impact on Bank MED Stability}

As shown in the table of coefficients, the independent variable "Bank MED" is highly significant at a $95 \%$ confidence level ( $\mathrm{p}$-value $=0.000<0.05)$.

The coefficient B1 is equal to -0.153 , which means that when capital adequacy increases by one percent, the stability of bank MED by 0.586 unit.

Table 6: Impact of capital adequacy on stability of Bank MED

\begin{tabular}{|c|c|c|c|c|c|c|}
\hline \multirow{2}{*}{\multicolumn{2}{|c|}{ Model }} & \multicolumn{2}{|c|}{$\begin{array}{c}\text { Unstandardized } \\
\text { Coefficients }\end{array}$} & \multirow{2}{*}{$\begin{array}{c}\begin{array}{c}\text { Standardized } \\
\text { Coefficients }\end{array} \\
\text { Beta }\end{array}$} & \multirow[b]{2}{*}{$\mathrm{t}$} & \multirow[b]{2}{*}{ Sig. } \\
\hline & & B & Std. Error & & & \\
\hline & $\begin{array}{l}\text { (Constant } \\
\text { ) }\end{array}$ & 2.965 & .353 & & 8.393 & .000 \\
\hline & MED & -.153 & .025 & -.907 & -6.097 & .000 \\
\hline
\end{tabular}

\subsubsection{IBL Bank}

\section{H g: Capital Adequacy has significant impact on IBL Bank Stability}

As shown in the Anova table that there is overall insignificance in addition to coefficients table, the independent variable "IBL Bank" is not significant at a 95\% confidence level. Thus,no significant impact of capital adequacy on IBL bank stability.

Table 7: Impact of capital adequacy on stability of IBL Bank

\begin{tabular}{|c|c|c|c|c|c|}
\hline \multirow[b]{2}{*}{ Model } & \multicolumn{2}{|c|}{$\begin{array}{l}\text { Unstandardized } \\
\text { Coefficients }\end{array}$} & \multirow{2}{*}{$\begin{array}{c}\begin{array}{c}\text { Standardized } \\
\text { Coefficients }\end{array} \\
\text { Beta }\end{array}$} & \multirow[b]{2}{*}{$\mathrm{t}$} & \multirow[b]{2}{*}{ Sig. } \\
\hline & B & Std. Error & & & \\
\hline $\begin{array}{l}1 \quad \text { (Constant } \\
\quad)\end{array}$ & .222 & .585 & & .380 & .714 \\
\hline IBL & -.001 & .030 & -.015 & -.043 & .967 \\
\hline
\end{tabular}




\subsubsection{Bank of Beirut}

\section{H h: Capital Adequacy has significant impact on Bank of Beirut Stability}

As shown in the table of Anova as well as coefficients, the independent variable "Bank of Beirut" is not significant at a $95 \%$ confidence level. That refers that that no significant impact of capital adequacy on Bank of Beirut stability positively or negatively.

Table 8: Impact of capital adequacy on stability of Bank of Beirut

\begin{tabular}{|c|c|c|c|c|c|c|}
\hline \multirow{2}{*}{\multicolumn{2}{|c|}{ Model }} & \multicolumn{2}{|c|}{ Unstandardized Coefficients } & \multirow{2}{*}{$\begin{array}{c}\begin{array}{c}\text { Standardized } \\
\text { Coefficients }\end{array} \\
\text { Beta }\end{array}$} & \multirow[b]{2}{*}{$\mathrm{t}$} & \multirow[b]{2}{*}{ Sig. } \\
\hline & & $\mathrm{B}$ & Std. Error & & & \\
\hline 1 & (Constant) & -2.350 & 3.840 & & -.612 & .558 \\
\hline & $\begin{array}{l}\text { BANKOFB } \\
\text { EIRUT }\end{array}$ & .260 & .278 & .314 & .936 & .376 \\
\hline
\end{tabular}

\section{Conclusion:}

This research paper intention is to study the capital adequacy requirements in the Lebanese banks and the effect of this ratio on the financial stability (indicated by Altman's z-score), by collecting the data of a sample of Lebanese banks to test the impact of their CAR on the financial stability of the bank.

Simple linear regression was conducted for each bank to test the impact of its capital adequacy ratio on its stability.

The results show that almost in all banks (except bank MED) there was no significant impact of CAR on the stability of the banks. This result shows that the commitment of Lebanese commercial banks under the monitoring of the central bank was not enough to keep the financial system stable, which is a logical conclusion after what happened in 2019 where the financial system has collapsed and the commercial banks faced a severe crisis in its liquidity and reputation. 
In his research "Impact of Capital Adequacy on the Performance of Nigerian Banks using the Basel Accord Framework", Abdul (2017) found that there is a positive impact of capital adequacy on a bank's profitability and stability. Also, the author Sang (2021) found in his study" "Capital adequacy ratio and a bank's financial stability", that the capital adequacy ratio has a positive correlation with the financial stability of commercial banks during his study period. Many previous and related studies have found this positive impact of capital adequacy ratio on the stability of banks in many countries.

However, few studies have found in some countries that there is no statistically significant impact of CAR on stability of banks. For instance, Michael Gou (2017) in his study" Did Capital Requirements Promote Bank Stability: Lessons from the National Banking Era”, found that capital requirements did not result in lower suspension rates or enhance financial stability.

Although the central bank in Lebanon was in a full compliance with Basel requirements concerning minimum capital over years, the Lebanese banking sector has collapsed and bankrupted. Also, depositors were not protected and they lost their deposited money in the bank. In other words, capital requirements in Lebanon did not prevent banks from engaging in excessive risk-taking and enhance financial stability.

The problem of the Lebanese banking sector could be mismanagement, concentration of the loans portfolio in Eurobonds and with the central bank, and many other factors that caused the financial collapse in Lebanon.

This could be investigated in future researches.

After analyzing results of this study and related studies, the following recommendations are written below:

To sustain banks' financial strength and stability, regulators should focus not only on capital adequacy but also on supervisory review and market discipline.

According to studies, the asset quality of a bank's portfolio has a significant impact on its performance. Poor and risky investments stifle growth, but a well-diversified, highquality asset improves performance. 
Studies and reports should be conducted to explain why capital adequacy ratios in Lebanon have not raised the financial stability of the banking sector, and why it failed in protecting depositors' rights.

\section{References:}

ABDU1, J. M. (2017). Impact of capital adequacy on the performance of Nigerian Banks using the Basel Accord Framework. East Africa Research Papers in Business, Entrepreneurship and Management.

Allen, F., \& Gale, D. (2003). Capital adequacy regulation: in search of a rationale. Economics for an imperfect world: Essays in honor of Joseph Stiglitz, 83-109.

Arab Banks Journal. (1992). Arab Banks Journal.

Aspal, P. K. (2014). An Empirical Analysis of Capital Adequacy in the Indian Private Sector Banks. American Journal of Research Communication, 28-42.

Barfield, R. (2020). A PRACTITIONER'S GUIDE TO BASEL III AND BEYOND. PricewaterhouseCoopers LLP.

Barth, J., Caprio, G.J., G., \& Levine, R. (2006). Rethinking Bank Regulation: Till Angels Govern”, New York: Cambridge University Press. New York: Cambridge University Press.

Calem, P., \& Rob, R. (1996). The impact of capital based regulation on bank risk-taking: A dynamic model, board of governors of the Federal Reserve System. Finance and Economics, Discussion Series 96/12 (February), 36.

Chavez, M. (2007). BASEL II - PILLAR II Main Guidelines and Practicalities of its Implementation. Amsterdam: Free University of Amsterdam.

Chbeir, R. (2019, 5 18). A Historical Analysis of Lebanon's Public Debt. Retrieved from blog.blominvestbank.com: https://blog.blominvestbank.com/wp- 
content/uploads/2019/05/A-Historical-Analysis-of-Lebanon\%E2\%80\%99s-PublicDebt.pdf

Chotalia, P. (2014). Evaluation of Financial Health of Sampled Private Sector Banks. Research Revolution, volume2, 7-11.

corporatefinanceinstitute. (2021). Basel I. Retrieved from www.corporatefinanceinstitute.com: https://corporatefinanceinstitute.com/resources/knowledge/finance/basel-i/

Datta, C., \& Mahmud, A. (2018). Impact of Capital Adequacy on Profitability Under Basel II Accord: Evidence from Commercial Banks of Bangladesh . European Journal of Business and Management, volume 10, 48-58.

Eichberger, J., \& Summer, M. (2015). Bank Capital, Liquidity, and Systemic Risk. Journal of the European Economic Association, Volume 3, 547-555.

Elia, J. Y. (2020). Lebanese banks: a factor of the current Lebanese financial crisis (20192020). Beirut: edoc.bseu.by. Retrieved from http://edoc.bseu.by:8080/bitstream/edoc/83186/1/Jean_Y._Elia_p_333-335.pdf

Flint, M. (2020, jan 8). cash flow reason small businesses fail. Retrieved from www.preferredcfo.com: https://www.preferredcfo.com/cash-flow-reason-smallbusinesses-fail/

Ghosn, F. (2019). Testing Z-Score Model on Lebanese Listed Banks. Research Journal of Finance and Accounting, 10 (12),, 78-85.

Goddard, J., Molyneux, P., \& Wilson, J. (2004). The profitability of European banks: A cross sectional and dynamic panel analysis. . The Manchester School, 72 (3),, 363-381.

Gou, M. (2017). Did Capital Requirements Promote Bank Stability: Lessons from the National Banking Era. California : University of California at Irvine. 
Hannoun, H. (2010, 11 22). Deputy General Manager, Bank for International Settlements, Speech at the BoJ-BIS High Level. Retrieved from www.bis.org: http://www.bis.org/speeches/sp101125a.pdf.

Harward, P., \& Upton, A. (1991). Introduction to Business Finance. New York; Mc Graw Hill.

Igbinosa, S., \& Naimo, F. (2020). CAPITAL ADEQUACY AND BANK

STABILITY/SOUNDNESS IN SUBSAHARA AFRICA. European Journal of Accounting, Finance and Investment, vol 6.

King, P., \& Tarbert , H. (2011). Basel III: An Overview . Banking and Financial services policy report, 1-38.

Kota, H. B. (2018, 10 19). Small businesses, big contribution. Retrieved from Dailypioneer.com: https://www.dailypioneer.com/2018/columnists/small-businesses--big-contribution.html

Merton, R. (1977). An analytic derivation of the cost of deposit insurance loan guarantees. . Journal of Banking and Finance, 1, 3-11.

Morgan, G. (1984). On the Adequacy of Bank Capital Regulation. Journal of Financial Quantitative Analysis, 141-162.

Mustafa, S. A. (2019). تحليل كفاية رأس المال الدصرفي وأثره في الدخاطر المصرفية وفق الدعابير الدولية: Arbil: salahaddin university college of administration and economics.

Obadan, M. (2004). Mergers and Acquisition and the new Minimum Capital. Financial Standards, 34.

OGBOI, C., \& UNUAFE, O. (2013). Journal of Emerging Issues in Economics, Finance and Banking (JEIEFB). Impact of Credit Risk Management and Capital Adequacy on the Financial Performance of Commercial Banks in Nigeria, 703-717.

Pasiouras, F., Kosmidou, K., \& Gaganis, C. (2006). A Pooled Study of the Internal and External Determinants of Australian Banks Profits and Margins. Crete: Working Paper, Financial Engineering Laboratory, Technical University of Crete. 
Patel, U. (2010). Cash Management at Indian oil Corporation Ltd. india: Patil University.

saleh, h. (2012). Managing the fiscal deficit in the Lebanese public budget from a strategic perspective. صوت الجامعة الاسلامبية, 184-211.

Sang, N. M. (2021). Nguyen Minh Sang (2021). Capital adequacy ratio and a bank's financial stability. Banks and Bank Systems, 16(4), 61-71.

SENTERO, D. R. (2012). THE EFFECT OF CAPITAL ADEQUACY REQUIREMENTS ON THE EFFICIENCY OF COMMERCIAL BANKS IN KENYA. NAIROBI: UNIVERSITY OF NAIROBI.

Vyas, R. (2008). The Impact of Capital Adequacy Requirements on Performance of Scheduled Commercial Banks. Asia-Pacific Journal of Management Research and Innovation.

Doi: $\underline{\text { doi.org/10.52133/ijrsp.v3.28.13 }}$ 